A final chapter is largely devoted to a discussion of the problem of the soul as it bears upon the experimentalist's work. Mr. Stratton adopts the position now so commonly held, that psychology needs no tertium quid beyond its states of consciousness, and at the same time he makes it abundantly clear that such a doctrine carries with it no necessary prejudice to the reality and sanctity of human personality. James Rowland Angell.

University of Chrcago.

\title{
PHILOSOPHICAL.
}

The Development of Modern Philosophy, with other Lectures and Essays. Robert Adamson. Edited by N. R. Sorley. 2 vols. Edinburgh and London. 1903. Pp. xlviii $+35^{8}$ and $x v$ +330 . 18 s. net.

These handsome volumes are the posthumous legacy of the late Professor Adamson. The first volume contains a sketch of modern philosophy from Descartes to Hegel, and also the sketch of a theory of knowledge. Volume two covers seven occasional papers, and besides the Principles of Psychology covering pp. 16I-330. The first volume has an excellent portrait of the author, a memorial 'introduction' by Professor Sorley, and a bibliography (arranged by years). ${ }^{1}$

The remarkable thing about these volumes is their maturity of expression and argument, seeing that they are made up of students' lecture notes and had no revision by the lecturer. The pages read with all the deliberate weighing of reasons and choosing of words of a labored composition.

In his views Adamson is one of the sanest and surest of those who reverted to a judicious naturalism largely under the weight of the evolution doctrine. His careful sense of fact and reverence for reality show in all the constructive parts. In the psychology we find a frank acceptance of the genetic point of view and a successful criticism of the logical and faculty doctrine; but yet we miss the definiteness of well-thought-out theory. He usually stops by saying in effect that any formula here or there must take account of development; but having said so much he does not work out sufficiently well-developed genetic principles to solve the problems which the development hypothesis raises. No doubt we miss here just what he would himself have aimed to give had he prepared the manuscripts for publication. Speaking of

1 The present writer takes interest in the fact that Adamson's last work was the series of articles on logical topics contributed to Vol. I. of the Dictionary of Philosophy and Psychology ( 83 titles). 
the psychology only we may say that it is a fair and fine statement of the transition - and its grounds - to the current genetic point of view. Of especial interest and value are the chapters on thought - a topic on which reconstructive theories are in the air - although $I$ find the value mainly critical and the interest mainly personal.

\section{David Hume and His Influence on Philosophy and Theology.}

James Orr. The World's Epoch-Makers. New York, Scribners (imported). 1903. Pp. viii + 246. \$1.25.

Rousseau und Naturalism in Life and Thought. W. H. Hudson. Same, 1903. Pp. $x+260$.

These are interesting additions to the series of 'Epoch-Makers'; they are liberal in the matter of biography, and the interpretations are broad and general in the interests of less philosophical readers. The volume on Hume goes into the theological bearings of that philosopher's work.

Naturalism and Agnosticism. James Ward. $2 \mathrm{~d}$ ed. 2 vols.

London, Black. r903. Pp. $x x+333$, and xiii +3 or.

In this edition - more than a year over-due - Professor Ward revises by adding notes addressed mainly to his critics. He again dwells upon details at issue with Mr. Spencer. Apart from the points themselves - and often they are too minute to count much in matters now mainly historical - the personal controversy is too spirited. It seems to the present writer that Professor Ward's original lectures were somewhat weakened by his animus in attacking in hundreds of pages a philosophy which to judge from his epithets was beneath attack! Spencer's work was epoch-making; he is a figure to reverence, no matter whether we agree with the Synthetic Philosophy or not. It is a phenomenon - this way Englishmen turn and rend their greatest living philosopher, seeming to forget that they are breathing a different intellectual atmosphere by virtue of his work! Spencer stands with Darwin - at least out of England! - a glory to the British intellect. ${ }^{1}$

In his notes now added Professor Ward touches upon many matters, always with a sure hand and large intelligence; he takes especial

1 All this apart from my essential agreement with my friend Professor Ward in most of his larger criticisms of cosmic evolution. It is just now reported that Mr. Spencer has been awarded a Nobel prize; outside of England at least such an award would generally be considered appropriate and old England congratulated that she has so fitting a candidate in the moral sciences !

It is indeed with 'reverence' that these lines are revised, being left to stand just as originally written, while Spencer lies dead at Brighton. 
pains to cite the best opinion in matters of physical science, even when it is necessary to modify the views expressed in his text. He is to be congratulated upon the wide circulation of the book, as well as upon the fact that he has by common consent made a permanent and very valuable contribution to philosophy. Many besides the writer hope that he will develop in a separate work the outline of the constructive views presented in the Volume II. before us - an outline most suggestive, but yet so sketchy that it is in some respects baffling and obscure. $^{1}$

J. M. B.

\section{NOTES AND NEWS.}

THE statement made in our last issue, on the authority of the daily press, to the effect that Dr. Scripture has resigned his position at Yale University, is erroneous. Dr. Scripture has been given leave of absence for a year to prosecute his researches on phonetics under a grant from the Carnegie Institution.

WE note in the published account of the past year's work of the Carnegie Institution that but two grants were made to psychologists (apart from certain Research Assistantships). This is certainly not a large 'plum,' and it does not go far toward the realization of the expectations excited by the report of the committee on psychology printed in the First Year-book. We sincerely hope that the present year will see the maturing of plans to develop larger undertakings in this and other subjects.

THE journal Kantstudien has issued a circular announcing the preparation of a Festheft on February I4, 1904, in commemoration of

${ }^{1}$ One of the longest notes in Volume I. deals with the view of evolution worked out recently by several writers, and called by the present reviewer 'Organic Selection' and 'Orthoplasy.' Professor Ward follows out his earlier suggestion that this view runs parallel with his own theory of 'Subjective Selection.' In this note he agrees with the writer (see the recent book, Development and Evolution, pp. 48, 108) that the main point as regards the direction or determination of evolution by the individual's accommodations was not enforced by him : but he holds that the process involved, so far as conscions selection is concerned, is what he called subjective selection - a statement in which I fully concur. I confess I do not see the force of the criticism of the name 'Organic Selection '; it overlooks the use of 'organic ' as adjective to 'organism,' a usage as old and good as that which makes it adjective to 'organ,' $e$. $g$., the expressions 'organic world,' 'organic remains,' etc. (see Century and Standard Dictionaries). 